\section{Comparing Chemical and Biological Control Strategies for Twospotted Spider Mites in Mixed Production of Ivy Geranium and Impatiens}

\author{
Kiffnie M. Holt ${ }^{1}$, George Opit ${ }^{2}$, James R. Nechols ${ }^{3}$, \\ David C. Margolies ${ }^{3}$, and Kimberly A. Williams ${ }^{4,5}$
}

ADDITIONAL INDEX wORDs. bedding plants, bifenazate, Floramite, Impatiens wallevana, integrated crop management, integrated pest management, Pelargonium peltatum, Phytoseiulus persimilis, pest sampling, Tetranychus urticae

SUMMARY. Biological and chemical control strategies for the twospotted spider mite (TSM; Tetranychus urticae) were evaluated in a greenhouse experiment replicated over time in mixed production of ivy geranium (Pelgargonium peltatum 'Amethyst 96') and two impatiens cultivars (Impatiens wallevana 'Impulse Orange' and 'Cajun Carmine'). Chemical control using the miticide bifenazate was compared with two release strategies for biological control using the predatory mite, Phytoseiulus persimilis. Specific treatments included 1) a single application of bifenazate at $0.3 \mathrm{~g} \cdot \mathrm{L}^{-1}$ formulation $(22.6 \%$ a.i. $\left.) ; 2\right)$ a single release of predatory mites at a 1:4 predator to pest ratio based on sampled pest density; 3 ) a weekly release of predatory mites at numbers based on the area covered by the crop; and 4) an untreated control. TSM populations were monitored for 4 weeks. After another 4 weeks, when plants were ready for market, plant quality ratings were recorded. The number of TSM per leaf dropped for all treatments on all genotypes but increased in the untreated plants. On ivy geranium, the fact that there were significantly more TSM on untreated plants was not reflected in average plant quality, but it did reduce the proportion of containers rated as salable at full price compared with both chemical and biological control. On impatiens, both treatment and cultivar had significant effects on the mean plant quality rating and on the proportion of containers rated as salable at full price. The use of a sampling plan to determine the appropriate number of predators to release was as effective as the currently recommended management treatments for TSM in bedding plants.

$\mathrm{G}$ reenhouse production of ornamental plants poses special challenges for the manager

in terms of pest control. It is common to grow many different species and cultivars, each with different toler-

This research was supported by USDA Pest Management Alternatives Program (PMAP) Grant No. 2002-34381-12146.

This manuscript is Contribution no. 06-118-J from the Kansas Agricultural Experiment Station (KAES).

Voucher specimens of Tetranychus urticae and Phytoseiulus persimilis were deposited in the Kansas State University Museum of Entomological and Prairie Arthropod Research under Lot Numbers 135 and 154, respectively.

The use of trade names in this publication implies neither endorsement by the KAES of products named nor criticism of similar ones not mentioned.

We thank the following individuals from Kansas State University for their assistance: Xiaoli Wu, Junrui Zhi, and Fahad Alatawi for help with mite inoculations; James Higgins for statistical advice; and Lea Westervelt for help setting up the greenhouse facilities. We gratefully acknowledge Fischer USA, Inc., Boulder, CO 80301, for providing ivy geranium cuttings; Syngenta Seeds, Inc., Downers Grove, IL 60515, for providing impatiens seed; and Chemtura Corp., Middlebury, CT 06749, for donation of Floramite WP.

${ }^{1}$ Graduate Research Assistant, Department of Entomology, Kansas State University, Manhattan, KS 66506-4004.

${ }^{2}$ Postdoctoral Research Associate, Department of Entomology, Kansas State University, Manhattan, KS 66506-4004.

${ }^{3}$ Professor of Entomology, Department of Entomology, Kansas State University, Manhattan, KS 66506-4004.

${ }^{4}$ Professor of Horticulture, Department of Horticulture, Forestry, and Recreation Resources, Kansas State University, Manhattan, KS 66506-5506.

${ }^{5}$ Corresponding author. E-mail: kwilliam@ksu.edu.

2 ances to pests, in the same greenhouse area, especially during spring production of bedding plant species. In addition, bedding plants are grown with very tight spacing between pots or flats, which allows the rapid spread of a pest through the crop. Furthermore, there is little tolerance for visible pest damage because ornamental crops are valued solely for their aesthetic appearance (Skirvin and Williams, 1999). These are reasons for the common practice of spraying pesticides as preventative control or on a set schedule. However, the practice of preventative or calendar pest control in greenhouse ornamental crop production often results in unnecessary pesticide applications. These may reduce profitability by increasing the cost of production, including the cost of chemicals, the labor to apply them, and the resulting loss of labor efficiency when re-entry intervals into the treated area must be observed.

To overcome the current challenges facing pest control in bedding plants, a more intensive integrated pest management (IPM) system needs to be developed and adopted into practice. Two cornerstones of IPM are 1) to impose control tactics only when pests are present in economically damaging numbers and 2) to use all available means of control instead of simply relying on chemicals.

The twospotted spider mite (TSM) is a serious pest of greenhouse-grown ornamental crops because of its broad host range, good dispersal ability, high reproductive rate, and short life cycle (Van de Vrie, 1985). Moreover, because of their small size and tendency to inhabit the underside of leaves, they can go undetected until populations are already causing damage. Therefore, growers traditionally rely on preventative applications of miticides to avoid TSM problems. Biological

\begin{tabular}{llll}
\hline $\begin{array}{l}\text { Units } \\
\text { To convert U.S. to SI, } \\
\text { multiply by }\end{array}$ & U.S. unit & SI unit & $\begin{array}{l}\text { To convert SI to U.S., } \\
\text { multiply by }\end{array}$ \\
\hline 0.3048 & $\mathrm{ft}$ & $\mathrm{m}$ & 3.2808 \\
0.0929 & $\mathrm{ft}^{2}$ & $\mathrm{~m}^{2}$ & 10.7639 \\
3.7854 & $\mathrm{gal}$ & $\mathrm{L}$ & 0.2642 \\
2.5400 & inch $(\mathrm{es})$ & $\mathrm{cm}$ & 0.3937 \\
7.4892 & $\mathrm{oz} / \mathrm{gal}$ & $\mathrm{g} \cdot \mathrm{L}^{-1}$ & 0.1335 \\
1 & $\mathrm{ppm}$ & $\mathrm{mg} \cdot \mathrm{L}^{-1}$ & 1 \\
$\left({ }^{\circ} \mathrm{F}-32\right) \div 1.8$ & ${ }^{\circ} \mathrm{F}$ & ${ }^{\circ} \mathrm{C}$ & $\left(1.8 \times{ }^{\circ} \mathrm{C}\right)+32$
\end{tabular}


control offers an alternative for managing TSM. The most frequently used biological agent for TSM is the predatory mite, Phytoseiulus persimilis (Acari: Phytoseiidae) (Gillespie and Raworth, 2004). A primary advantage of using predatory mites is that the predators are mass-produced in commercial insectaries and are readily available for purchase by greenhouse managers. Biological control of TSM by predatory mites has proven effective on some ornamental crops produced in greenhouses (Burnett, 1979; Chant, 1961; Gough, 1991; Gould and Light, 1971; Hamlen, 1978; Kropczynska et al., 1999; Simmonds, 1972). Despite these successes, growers are reluctant to use biological control. The reasons they give include producing more than one crop in a greenhouse, a low threshold for damage, zero tolerance for pests, and lack of information on the implementation and use of biologicals (Dekeyzer, 1999; Enkegaard et al., 1999). Many growers also believe that biological controls are too costly and are not practical to implement in their greenhouses (Schumacher, 2002).

The work reported here addresses some of the reasons why biological control is underused in ornamental production and whether avoidance of biological control is justified based on efficacy and economics. It includes the use of two common and economically important ornamental crops, ivy geranium and impatiens, which have different tolerances to the pest and therefore different damage thresholds (Alatawi, 2006; Opit et al., 2005). Biological control is compared with chemical control with a "reduced-risk" miticide, bifenazate, which is a relatively new chemical in the carbazate chemical class. It acts as a $\gamma$-aminobutyric acid (GABA) antagonist on the nervous system of the pest and also has some ovicidal activity. Bifenazate is effective against TSM, red mites, and grass mites (Acari: Tetranychidae) but is not effective against rust mites (Acari: Eriophyidae), broad mites [Polyhagotarsonemus latus (Acari: Tarsonemidae)], or flat mites [Brevipalpus spp. (Acari: Tenuipalpidae)]. According to the label, it should not adversely affect many beneficial arthropods, including predatory mites.
Although TSM numbers serve as one measure of treatment effectiveness, the ultimate success of TSM control strategies should also be evaluated using plant quality ratings based on salability, which relates to the economics of using biological control. The objectives of this study were, therefore, to compare the effectiveness of a biological control (specifically, a predatory mite) with that of chemical control (bifenazate) and to determine if the specific protocol for releasing predators affected TSM suppression and plant damage. In addition, the differences in damage prevention by these control strategies between ivy geranium and impatiens, and between two different cultivars of impatiens, were evaluated.

\section{Materials and methods}

General Procedures. Two cultivars of impatiens (Impulse Orange and Cajun Carmine) and one cultivar of ivy geranium (Amethyst 96) were used. Impatiens seeds were provided by Syngenta USA (Downers Grove, Ill.). The impatiens were propagated from seed in 406-cell plug trays (TLC Polyform, Plymouth, Minn.), with 3 weeks from sowing to transplant. Seedlings were transplanted into 1801 cell packs $(7 \times 7-\mathrm{cm}$ square, black standard flat inserts; ITML Horticultural Products, Brantford, Ontario, Canada) that were placed in $10.5 \times 21$-inch black standard flats (ITML Horticultural Products) on expanded metal-top, pipe-frame benches. Ivy geranium were grown from cuttings taken from plants maintained in the Throckmorton Plant Sciences Center (TPSC) greenhouses at Kansas State University, Manhattan. The stock was originally provided by Fischer USA (Boulder, Colo.). Ivy geranium cuttings were rooted under mist for 4 weeks before being transplanted into $20-\mathrm{cm}$-diameter round, green hanging baskets (ITML Horticultural Products), with three cuttings per basket. All plants were grown in ProMix BX root media (Premier Horticulture Ltd., Dorval, Quebec) and fertilized until maturity with $200 \mathrm{mg} \cdot \mathrm{L}^{-1}$ nitrogen from $20 \mathrm{~N}-$ 4.3P-16.6K fertilizer (Peter's Peatlite; Scotts Co., Marysville, Ohio) at every watering. The fertilizer solution was applied when the surface of the root medium became a lighter color, indicating dry down.

The experiment was conducted in a $69.4-\mathrm{m}^{2}$ glass greenhouse at the TPSC. Three temporal replications were conducted from 19 March to 9 May 2003 (replication 1); from 5 May to 27 June 2003 (replication 2); and from 1 Feb. to 28 Mar. 2004 (replication 3 ). The experimental design was a replicated split plot design. In each replication, we used one bench for each of the four treatments with the exception of the first replication when we lacked the untreated control. Therefore, all treatments were replicated three times with the exception of the untreated control, which was only replicated twice.

Each bench had three rows of plants: a row each of 'Impulse Orange' and 'Cajun Carmine' impatiens flats with a row of 'Amethyst 96' ivy geranium baskets between them. The whole plot experimental unit is defined as all plants on a bench (ivy geranium baskets and impatiens flats) receiving the same pest control treatment; the subplot experimental unit is defined as plants in a given row. The whole plots in replications 1 and 3 included seven flats of each impatiens cultivar and 14 baskets of ivy geranium, while replication 2 had four flats of 'Impulse Orange', five flats of 'Cajun Carmine', and nine baskets of ivy geranium. In replication 1 , three treatments (one chemical and two biological) were compared for their ability to manage TSM and prevent plant damage. In replications 2 and 3 , an untreated control was included as well. Treatments were randomly assigned to individual greenhouse benches (i.e., whole plots) and were applied 4 weeks after transplanting.

Benches were oriented in the greenhouses so that their length was perpendicular to the cooling pads along one wall and the exhaust fans along the other, and thus parallel to the temperature gradient. To prevent TSM and predatory mites from moving among the benches, two physical barriers were used. First, walls of 6-mil plastic sheeting were hung between treatment benches. These extended from just below the fan-jet tube ( $\approx 3 \mathrm{~m}$ above the floor) to the floor and from the cooling pads to within $2 \mathrm{~m}$ of the exhaust fans, thus extending several meters beyond the plants in both directions. A second 
barrier consisted of a layer of Tangle Trap (Tanglefoot Co., Grand Rapids, Mich.) on all legs of the benches that held the treatments. Therefore, the TSM and predatory mites might move among species and cultivars within a bench but not among the benches themselves.

Two weeks after transplanting, all crops were inoculated with TSM taken from colonies maintained for $>6$ years on lima bean plants (Phaseolus lunatus) in temperature-controlled rearing rooms at $25 \pm 3{ }^{\circ} \mathrm{C}$ and photoperiod of 16:8 h light/ dark. The TSM were introduced at an average rate of $0.2 \mathrm{TSM} / \mathrm{cm}^{2}$ of leaf area. This was accomplished by first calculating the average leaf area per ivy geranium basket and impatiens flat. To simulate a "hot-spot" distribution of a natural TSM infestation, each basket or flat was randomly assigned to either a high or low inoculation rate of TSM using a random number table. Half of the pots or flats received the high level, and half received the low level. Adult female TSM were counted onto lima bean leaf disks that were then transferred to the crops. For the high inoculation rate, two leaf disks were placed on each flat or basket; for the low rate, only one leaf disk was used. The actual inoculation rates varied slightly among replications over time depending on leaf area of the crop. The average numbers of TSM released per ivy geranium basket were 77 and 25 for high and low rates, respectively. The average numbers of TSM released per impatiens flat were 83 and 28 for high and low rates, respectively.

Treatments. The three pest control strategies used were l) single application of miticide; 2) single release of the predatory mites with numbers released based on TSM density (targeting a 1:4 predator to pest ratio); and 3) weekly release of predatory mites with numbers released based on crop area as recommended by the commercial supplier of the predator. An untreated control was added to replications 2 and 3 to ensure that there was no natural decrease in TSM numbers. For the chemical control treatment, a single application of bifenazate (Floramite WP, 22.6\% a.i.; Chemtura Corp., Middlebury, Conn.) at a rate of $0.3 \mathrm{~g} \cdot \mathrm{L}^{-1}$ formulation was sprayed to runoff using an 8 -L pressurized sprayer.
For the biological control treatments, shipments of the predatory mite were obtained from a commercial insectary (Koppert Biological Systems, Romulus, Mich.). Predators were transferred to plants within $24 \mathrm{~h}$ of receipt. The numbers of predators released was determined by the specific treatment. The area-based predator release treatment consisted of four weekly predator releases based on the area covered by the crop and the recommended preventative rate of 50 predatory mites $/ \mathrm{m}^{2}$. The area covered by the crop in replications 1 and 3 was $3 \mathrm{~m}^{2}$ and $1.9 \mathrm{~m}^{2}$ for replication 2 . The actual weekly numbers released in this treatment for replications 1,2 , and 3 were 150 , 95 , and 150 , respectively.

The sampling-based predator treatment consisted of a single release of predatory mites based on an estimation of the number of TSM present on the ivy geranium baskets on the bench assigned to this treatment. This estimate was calculated from the following formula (Opit et al., 2003):

$$
\text { TSM per } \mathrm{m}^{2}=M_{\mathrm{s}} \cdot \beta^{-1} \cdot \gamma^{-1} \cdot \rho \cdot \lambda^{-1}
$$

where $M_{\mathrm{s}}=$ TSM density from sampling, $\beta=0.255$ [the proportion of total TSM on all young, fully opened leaves that are on the sampled young, fully opened leaves; allows for plant age (Wilson et al., 1983)], $\gamma=0.294$ [the proportion of total TSM that are on young, fully opened leaves; also allows for plant age (Wilson et al., 1983)], $\rho=9$ (plants per meter-row; three 20 -cm-diameter baskets $\times$ three plants per basket in each meter-row), and $\lambda=30.5 \mathrm{~cm}$ (spacing between rows, rows per meter).

Estimated numbers of TSM per square meter of ivy geraniums were 2784,1279 , and 2951 for replications 1,2 , and 3 , respectively. Numbers of predators to release were computed according to a $1: 4$ predator to pest ratio (Opit et al., 2004). For replications 1,2 , and 3 , totals of 2088, 608 , and 2211 predatory mites, respectively, were released on benches assigned to the sampling-based predator treatment.

After treatments were applied, TSM populations were monitored weekly by counting all non-egg forms on leaf samples from ivy geraniums (Opit et al., 2003) and impatiens
(Alatawi et al., 2005). Mites were counted on 30 leaves per cultivar per week for a period of 4 weeks after treatments were applied. Eight weeks after transplanting (4 weeks after treatments were applied), the experiments were ended and plant condition was rated using a 10-point visual ranking system based on the degree of visible TSM damage to the plant. Based on Opit et al. (2004, 2005), the following ratings equated to salability of the crops: $8.5-10=$ full price; $7-8=$ discounted; and below $7=$ discarded.

Statistical anAlysis. All analyses were performed using the PROC MIXED procedure (SAS/STAT version 8.1; SAS Institute, Cary, N.C.). The design for analysis of TSM counts was a replicated split-plot design with repeated measures. All plants on a bench receiving the same pest control treatment comprised the whole plot experimental unit, while the rows of 'Impulse Orange' and 'Cajun Carmine' impatiens and 'Amethyst 96' ivy geranium on each bench were subplots. Repeated measures were done on the subplot experimental units. At each sample date, TSM were counted on a random sampling of leaves of a certain age. Therefore, it is unlikely that the same leaf was ever sampled twice; however, each subplot was resampled at each date. The analysis involving TSM counts tested for treatment, cultivar, and sample date; main effects and interactions were evaluated. When a significant threeway interaction occurred $(P=0.05)$, the data were reanalyzed within cultivar and sample date.

The design for analysis of plant ratings data were a replicated split plot design. Plant ratings data included both the mean of the ratings and the proportion of plants that were rated at full price. These data were analyzed to examine the main effects of treatment and cultivar and were then sorted by cultivar to isolate the effect of treatment. Before analysis, the proportion data were transformed using the arcsine transformation to stabilize variance. The criteria for significance was $P=$ 0.05 for analyses of mean plant rating. However, we decided a priori to use $P=0.01$ for the analysis of proportion data because of the small number of observations and the high degree of variability normally encountered when working with TSM populations. 
Because the untreated control treatment was included only in replications 2 and 3, data were analyzed by treating lack of the control in replication 1 as missing data. To confirm these results, analysis was done using only data from replications 2 and 3. Only one inconsequential difference in results of the two analyses occurred; therefore, only results of the first analysis-where the lack of an untreated control in replication $l$ is treated as missing data-is included in this manuscript.

Finally, because replications 1 , 2 , and 3 occurred over an $\approx 1$-year period, the effect of replication was tested using the PROC GLM procedure (SAS/STAT version 8.1); it was not significant $(F=0.01 ; \mathrm{df}=2$; $P=0.9914$ ).

\section{Results and discussion}

All treatments that received some form of pest management resulted in plants with very few or no TSM by the end of the replication, while in the untreated control the TSM population grew exponentially throughout the 4-week test period (Table 1). The overall analysis of TSM counts showed treatment $(F=$ $37.72 ; \mathrm{df}=3,2 \mathrm{l} ; P=0.0001)$ and sample date $(F=19.32 ; \mathrm{df}=3,63 ; P=$ $0.0001)$ to have significant effects on mean number of TSM per leaf. A significant two-way interaction between treatment and sample date $(F=25.37 ; \mathrm{df}=9,63 ; P \leq 0.0001)$ was also observed. This can be attributed in part to the increase in TSM numbers on untreated plants and in part to differences in the rate at which TSM populations decreased on treated plants. On bifenazate-treated plants, the TSM population diminished to and remained at undetectable levels within 1 week, while the two biological control treatments did not produce comparable results until the end of the third week (Table 1 ).

Both the biological and chemical control measures were ultimately effective in suppressing pest populations. However, mean damage showed a different trend reflecting varied plant sensitivity to TSM. Treatment $(F=20.84 ; \mathrm{df}=3,5 ; P=0.0030)$ and cultivar $(F=9.79 ; \mathrm{df}=2,14 ; P=$ 0.0022 ) had significant effects on mean plant ratings (Table 2). TSM feeding damage occurs when they insert their mouthparts into the epidermal cells of plant leaves, causing small discolored spots, called stippling. This stippling can develop more quickly on a thinner leaf, like that of impatiens, than on a thicker leaf like that of ivy geranium. When sorted by cultivar, 'Amethyst 96' ivy geranium showed no statistical difference $(F=2.16 ; \mathrm{df}=3,5 ; P=0.2112)$ in mean plant ratings between treated and untreated plants, regardless of the type of treatment. Visible damage to 'Amethyst 96' ivy geranium cultivar was minimal, and this was reflected in the lack of significance.
In contrast, 'Cajun Carmine' and 'Impulse Orange' impatiens showed significantly more damage on untreated plants compared with plants treated with either chemical or biological controls, but there was no difference between plants treated with chemical or biological agents. In the analysis of the plant ratings data, there was no significant interaction between treatment and cultivar $(F=$ $2.41 ; \mathrm{df}=6 ; P=0.0819)$.

Although the mean damage ratings suggest that all three pest management options acted equally in protecting the crop from damage, the proportion of units that might be sold at full price revealed cultivarspecific differences among treatments in perceived marketability of the crop (Table 3). Units that were rated below full price were likely those that received the high rate of TSM in the inoculation. When plant ratings were analyzed in detail as the proportion of the baskets or flats rated at full price, cultivar $(F=7.96 ; \mathrm{df}=2,14 ; P=$ $0.0049)$ and treatment $(F=17.45$; $\mathrm{df}=3,5 ; P=0.0044)$ were significant. In addition, a significant two-way interaction between cultivar and treatment $(F=3.14 ; \mathrm{df}=6,14 ; P=$ 0.0363 ) was found. When sorted by cultivar, treatments were significantly different on ivy geranium 'Amethyst 96' $(F=4.10 ; \mathrm{df}=3,5 ; P=0.0815)$ and both 'Impulse Orange' $(F=$ $26.42 ; \mathrm{df}=3,5 ; P=0.0017)$ and 'Cajun Carmine' $(F=23.60 ; \mathrm{df}=3,5$;

Table 1. Mean (SE) number of twospotted spider mites (TSM) per sampled leaf for each species and cultivar are shown for each sample date $(N=90$ for all treatments except the untreated control, for which $N=60)$.

\begin{tabular}{|c|c|c|c|c|c|c|}
\hline \multirow[b]{2}{*}{ Species/cultivar } & \multirow[b]{2}{*}{ Treatment $^{\mathrm{y}}$} & \multicolumn{5}{|c|}{ TSM [mean no./leaf $(\mathrm{SE})]^{\mathrm{z}}$} \\
\hline & & Pre-count $^{\mathrm{x}}$ & Week 1 & Week 2 & Week 3 & Week 4 \\
\hline \multicolumn{7}{|l|}{ Ivy geranium } \\
\hline \multirow{3}{*}{ Amethyst 96} & Sample-based & 1.49 & $0.6(0.20) \mathrm{ab}$ & $0.3(0.07) \mathrm{a}$ & $0.0(0.01) \mathrm{a}$ & $0.0(0.02) \mathrm{a}$ \\
\hline & Area-based & & $1.9(0.29) \mathrm{ab}$ & $0.5(0.12) \mathrm{a}$ & $0.0(0.00) \mathrm{a}$ & $0.0(0.03) \mathrm{a}$ \\
\hline & Untreated & & $2.6(0.51) b$ & $2.7(0.32) b$ & $7.1(0.70) \mathrm{b}$ & $6.4(0.77) b$ \\
\hline \multirow{3}{*}{ Impulse Orange } & Sample-based & 1.29 & $0.5(0.13) \mathrm{ab}$ & $0.2(0.07) \mathrm{a}$ & $0.5(0.17) \mathrm{a}$ & $0.2(0.11) \mathrm{a}$ \\
\hline & Area-based & & $0.8(0.18) \mathrm{ab}$ & $0.6(0.15) \mathrm{a}$ & $0.1(0.06) \mathrm{a}$ & $0.1(0.09) \mathrm{a}$ \\
\hline & Untreated & & $2.3(0.42) \mathrm{b}$ & $3.4(0.66) \mathrm{b}$ & $5.7(0.98) b$ & $12.6(1.60) b$ \\
\hline \multirow[t]{2}{*}{ Cajun Carmine } & Bifenazate & & $0.0(0.00) \mathrm{a}$ & $0.0(0.00) \mathrm{a}$ & $0.0(0.00) \mathrm{a}$ & $0.0(0.00) \mathrm{a}$ \\
\hline & Sample-based & 0.18 & $0.4(0.10) \mathrm{ab}$ & $0.1(0.05) \mathrm{a}$ & $0.0(0.00) \mathrm{a}$ & $0.0(0.02) \mathrm{a}$ \\
\hline
\end{tabular}

${ }^{2}$ Means within a cultivar and sample date followed by a different letter are significantly different at $P<0.05$ by LSD.

${ }^{y}$ Bifenazate $=$ single application of miticide; sample-based $=$ single release of 1 predatory mite $(P$. persimilis $): 4$ TSM, based on sampled TSM density; area-based $=$ weekly release of predatory mite, based on crop area with numbers recommended by commercial supplier; and untreated $=$ no TSM control.

Initial TSM counts obtained only from plants in the sample-based treatment. 
$P=0.0022)$ impatiens. On 'Amethyst 96' ivy geranium and 'Cajun Carmine' impatiens cultivars, all of the pest management treatments resulted in significantly more fullprice units than no treatment, but all treatments were equally effective. On 'Impulse Orange' impatiens, chemical and biological control also resulted in more full-price flats than no treatment, but chemical control resulted in more full-price flats than either biological control strategy. This measure of plant damage offers a slightly different, and probably a more realistic, assessment of treatment effects than does averaging plant damage.

Ivy geranium and impatiens, like most bedding plants, have a relatively short cropping time, from 2 to 10 weeks after transplant. Our findings suggest that predatory mites can be used effectively, even on short-term bedding plant crops, including some cultivars of TSM-sensitive species, as long as the treatments are applied soon after initial invasion of a crop. For example, we found symptoms on the impatiens within 1 week of inoculation. We recommend that scouting should be conducted on a regular basis as soon as plants are in the greenhouse to detect and treat TSM as soon as they appear. An alternative to scouting would be the scheduled, weekly release of predators, but the downside to multiple predator releases is the high cost, especially with respect to shipping. For example, when ordering small numbers of predatory mites, the cost of overnight shipping can be nearly as much as the cost of the predators themselves (Holt, 2005). Extremely sensitive cultivars, such as 'Impulse Orange' impatiens, may have to be treated with predatory mites preventatively

Table 2. Mean (SE) plant rating of all baskets of ivy geranium or flats of impatiens within a treatment are shown, according to a 1 to 10 scale (where $<7=$ discarded, $7-8=$ discounted, and $8.5-10=$ full price).

\begin{tabular}{lccc}
\hline & \multicolumn{3}{c}{ Mean plant rating (1-10 scale) } \\
\cline { 2 - 4 } Treatment $^{\mathbf{y}}$ & $\begin{array}{c}\text { Ivy geranium } \\
\text { Amethyst 96 } \\
\text { baskets }\end{array}$ & $\begin{array}{c}\text { Impatiens } \\
\text { Impulse Orange } \\
\text { flats }\end{array}$ & $\begin{array}{c}\text { Impatiens } \\
\text { Cajun Carmine } \\
\text { flats }^{\mathbf{z}}\end{array}$ \\
\hline Bifenazate & $9.6(0.11) \mathrm{a}$ & $9.4(0.51) \mathrm{a}$ & $9.3(0.17) \mathrm{a}$ \\
Sample-based & $(N=37)$ & $(N=18)$ & $(N=19)$ \\
Area-based & $9.7(0.09) \mathrm{a}$ & $8.9(0.19) \mathrm{a}$ & $9.2(0.17) \mathrm{a}$ \\
& $(N=37)$ & $(N=18)$ & $(N=19)$ \\
Untreated & $9.7(0.08) \mathrm{a}$ & $8.7(0.19) \mathrm{a}$ & $8.7(0.25) \mathrm{a}$ \\
& $(N=37)$ & $(N=18)$ & $(N=19)$ \\
& $8.5(0.16) \mathrm{a}$ & $6.1(0.33) \mathrm{b}$ & $6.7(0.30) \mathrm{b}$ \\
& $(N=23)$ & $(N=11)$ & $(N=12)$ \\
\hline
\end{tabular}

${ }^{2}$ Means within a cultivar followed by a different letter are significantly different at $P=0.05$ by LSD

${ }^{\mathrm{y}}$ Bifenazate $=$ single application of miticide; sample-based $=$ single release of 1 predatory mite $(P$. persimilis): 4 TSM, based on sampled TSM density; area-based = weekly release of predatory mite, based on crop area with numbers recommended by commercial supplier; and untreated = no TSM control.

Table 3. Mean proportion (SE) of baskets of ivy geranium or flats of impatiens rated at full price 8 weeks after application of treatments for control of twospotted spider mites (TSM).

\begin{tabular}{|c|c|c|c|}
\hline \multirow[b]{2}{*}{ Treatment $^{\mathrm{y}}$} & \multicolumn{3}{|c|}{ Mean proportion of units rated at full price } \\
\hline & $\begin{array}{c}\text { Ivy geranium } \\
\text { Amethyst } 96^{z} \\
\text { baskets }\end{array}$ & $\begin{array}{c}\text { Impatiens } \\
\text { Impulse Orange }^{\mathrm{z}} \\
\text { flats }\end{array}$ & $\begin{array}{c}\text { Impatiens } \\
\text { Cajun Carmine } \\
\text { flats }\end{array}$ \\
\hline Bifenazate & $\begin{array}{c}0.89(0.11) \mathrm{a} \\
\quad(N=3)\end{array}$ & $\begin{array}{l}1.00(0.00) \mathrm{a} \\
\quad(N=3)\end{array}$ & $\begin{array}{c}0.84(0.08) \mathrm{a} \\
\quad(N=3)\end{array}$ \\
\hline Sample-based & $\begin{array}{c}0.93(0.07) \mathrm{a} \\
\quad(N=3)\end{array}$ & $\begin{array}{c}0.63(0.10) \mathrm{b} \\
\quad(N=3)\end{array}$ & $\begin{array}{c}0.90(0.10) \mathrm{a} \\
\quad(N=3)\end{array}$ \\
\hline Area-based & $\begin{array}{l}1.00(0.00) \mathrm{a} \\
\quad(N=3)\end{array}$ & $\begin{array}{c}0.76(0.17) \mathrm{b} \\
\quad(N=3)\end{array}$ & $\begin{array}{c}0.76(0.24) \mathrm{a} \\
\quad(N=3)\end{array}$ \\
\hline Untreated & $\begin{array}{c}0.67(0.12) b \\
\quad(N=2)\end{array}$ & $\begin{array}{c}0.00(0.00) \mathrm{c} \\
\quad(N=2)\end{array}$ & $\begin{array}{c}0.00(0.00) \mathrm{b} \\
\quad(N=2)\end{array}$ \\
\hline
\end{tabular}

${ }^{2}$ Means within a cultivar followed by a different letter are significantly different at $P=0.1$ by LSD.

${ }^{y}$ Bifenazate $=$ single application of miticide; sample-based $=$ single release of 1 predatory mite $(P$. persimilis):4 TSM based on sampled TSM density; area-based = weekly release of predatory mite, based on crop area with numbers recommended by commercial supplier; and untreated = no TSM control. as opposed to reactively. A preventative strategy using predatory mites on ornamentals is a possible option to achieve control with minimal damage (Alatawi, 2006; Kropczynska et al., 1999; Skirvin and Williams, 1999). However, using predatory mites on a preventative basis again requires repeated applications over the course of the cropping cycle because this predator does not persist in the absence of prey (Chant, 1961; Hamlen and Lindquist, 1981). Multiple applications are likely to be more useful and perhaps cost-effective for longer-term ornamental crops, such as roses (Rosa spp.) and foliage plants on which predatory mites are used as a biological control agent of TSM (Burnett, 1979; Chant, 1961; Gould and Light, 1971; Gough, 1991; Hamlen, 1978; Kropczynska et al., 1999; Simmonds, 1972). Predatory mites might also be augmented with occasional applications of pesticides on these crops (Boys and Burbutis, 1972; Burnett, 1979).

The number of predatory mites released on all genotypes in the sampling-based predator treatment was calculated based on sampling the least-susceptible genotype, 'Amethyst 96' ivy geranium. To reduce aesthetic injury from TSM in production environments with a mix of resistant and susceptible species and cultivars, it would be appropriate to instead estimate predatory mite release rates from results of sampling the most susceptible genotype, which in this research is 'Impulse Orange' impatiens (Alatawi et al., 2005).

Biological control with predatory mites is an effective but underused option for managing TSM on greenhouse bedding plants. We found that the use of a sampling plan to determine an appropriate number of predators to release was as effective as two currently recommended scheduled treatments, namely, one with a chemical application and one requiring repeated predator releases without knowledge of TSM presence or numbers. It is important to note, however, that no TSM were found after chemical control, whereas an occasional TSM was found on crops treated with either biological control method. Although not statistically significant, this is an important difference for growers who attempt to accomplish complete pest kill with 
their pest management plan. None of the three TSM control measures resulted in $100 \%$ pest mortality, as indicated by the occurrence of some damage in all treatments. Therefore, our results show that when scouting is being conducted as part of a standard IPM program in bedding plant culture, it is possible to detect and effectively manage TSM infestations in moderately tolerant, though not very susceptible, bedding plants using predatory mites, without incurring loss of salable flats.

\section{Literature cited}

Alatawi, F.J. 2006. Development of biological control of twospotted spider mite, Tetranychus urticae Koch (Acari: Tetranychidae) on greenhouse impatiens, Impatiens wallerana Hook.f. $\mathrm{cv}$ 'Impulse Orange,' using the predatory mite, Phytoseiulus persimilis Athias-Henriot (Acari: Phytoseiidae). Dept. of Entomology, Kansas State Univ., Manhattan, PhD Diss.

Alatawi, F.J., G.P. Opit, D.C. Margolies, and J.R. Nechols. 2005. Within-plant distribution of twospotted spider mites, Tetranychus urticae Koch (Acari: Tetranychidae), on impatiens: development of a presence-absence sampling plan. J. Econ. Entomol. 98:1040-1047.

Boys, F.E. and P.P. Burbutis. 1972. Influence of Phytoseiulus persimilis on populations of Tetranychus turkestani at the economic threshold on roses. J. Econ. Entomol. 65:114-117.

Burnett, T. 1979. An acarine predatorprey population infesting roses. Res. Popul. Ecol. (Kyoto) 20:227-234.

Chant, D.A. 1961. An experiment in biological control of Tetranychus telarius (L.) (Acarina: Tetranychidae) in a greenhouse using the predacious mite Phytoseiulus persimilis Athias-Henriot (Phytoseiidae). Can. Entomol. 93:437-443.

Dekeyzer, M. 1999. Factors influencing the adoption of biological control technologies in floriculture under glass.
IOBC/WPRS (Intl. Org. Biol. Integrated Control Noxious Animals Plants, West Palearctic Reg. Section) Bul. 22(1):5760.

Enkegaard, A., D.F. Jensen, P. FolkerHansen, and J. Eilenberg. 1999. Present use and future potential for biological control of pests and diseases in Danish glasshouses. IOBC/WPRS (Intl. Org. Biol. Integrated Control Noxious Animals Plants, West Palearctic Reg. Section) Bul. 22(1):65-68.

Gillespie, D.R. and D.A. Raworth. 2004. Biological control of two-spotted spider mites on greenhouse vegetable crops, p. 185-199. In: K.M. Heinz, R.G. Van Driesche, and M.P. Parrella (eds.). Biocontrol in protected culture. Ball Publ., Batavia, Ill.

Gough, N. 1991. Long-term stability in the interaction between Tetranychus urticae and Phytoseiulus persimilis producing successful integrated control on roses in southeast Queensland. Exp. Appl. Acarol. 12:83-101.

Gould, H.J. and W.I. St. G. Light. 1971 Biological control of Tetranychus urticae on stock plants of ornamental ivy. Plant Pathol. 20:18-20.

Hamlen, R.A. 1978. Biological control of spider mites on greenhouse ornamentals using predaceous mites. Proc. Fla. State Hort. Soc. 91:247-249.

Hamlen, R.A. and R.K. Lindquist. 1981. Comparison of two Phytoseiulus species as predators of twospotted spider mites on greenhouse ornamentals. Environ. Entomol. 10:524-527.

Holt, K.M. 2005. Developing components of IPM for twospotted spider mite on greenhouse floricultural crops. Dept. of Entomology, Kansas State Univ., Manhattan, MS Thesis.

Kropczynska, A., A. Pilko, A. Witul, and A.-M. Asshleb. 1999. Control of twospotted spider mite with Amblyseius californicus on croton. IOBC/WPRS (Intl. Org. Biol. Integrated Control Noxious Animals Plants, West Palearctic Reg. Section) Bul. 22(1):133-136.
Opit, G.P., Y. Chen, K.A. Williams, J.R. Nechols, and D.C. Margolies. 2005. Plant age, fertilization and biological control affect damage caused by twospotted spider mites on ivy geranium: development of action thresholds. J. Amer. Soc. Hort. Sci. 130:159-166.

Opit, G.P., D.C. Margolies, and J.R. Nechols. 2003. Within-plant distribution of twospotted spider mite, Tetranychus urticae Koch (Acari: Tetranychidae), on ivy geranium: development of a presenceabsence sampling plan. J. Econ. Entomol. 96:482-488.

Opit, G.P., J.R. Nechols, and D.C. Margolies. 2004. Biological control of twospotted spider mites, Tetranychus urticae Koch (Acari: Tetranychidae), using Phytoseiulus persimilis AthiasHenriot (Acari: Phytoseidae) on ivy geranium: assessment of predator release ratios. Biol. Control 29:445-452.

Schumacher, S.K. 2002. Economic analysis of production and pest management decisions confronting greenhouse growers. Dept. of Agricultural Economics, Kansas State Univ., Manhattan, KS, PhD Diss.

Simmonds, S.P. 1972. Observations on the control of Tetranychus urticae on roses by Phytoseiulus persimilis. Plant Pathol. 21:163-165.

Skirvin, D. and M. Williams. 1999. The effect of plant species on the biology of Tetranychus urticae and Phytoseiulus persimilis. IOBC/WPRS (Intl. Org. Biol. Integrated Control Noxious Animals Plants, West Palearctic Reg. Section) Bul. 22(1):233-236.

Van de Vrie, M. 1985. Control of Tetranychidae in crops: greenhouse ornamentals, p. 273-284. In: W. Helle and M.W. Sabelis (eds.). Spider mites, their biology, natural enemies and control, Vol. IB. Elsevier, Amsterdam, The Netherlands.

Wilson, L.T., D. Gonzalez, T.F. Leigh, V. Maggi, C. Foristiere, and P. Goodell. 1983. Within-plant distribution of spider mites (Acari: Tetranychidae) on cotton: a developing implementable monitoring program. Environ. Entomol. 12:128134. 